\title{
Asking questions and seeking answers in population ecology: Harry Andreassen in Memoriam
}

\author{
Hannu Ylönen ${ }^{1} \cdot$ Rolf A. Ims ${ }^{2}$ \\ ๑) Springer-Verlag GmbH Germany, part of Springer Nature 2021
}

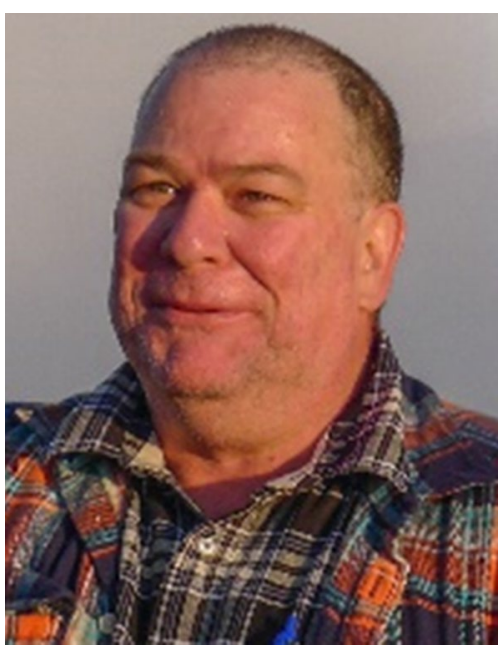

The paper by Andreassen et al. (2020) is dedicated to the memory of our dear colleague and friend, mammalian population ecologist Harry Peter Andreassen (1962-2019). Harry did his major scientific career at Hedmark College in Evenstad, currently Inland Norway University of Applied Sciences, first during his extensive PhD project with Rolf Anker Ims on spatial ecology of root voles in experimentally fragmented populations in enclosures. Later, after becoming a professor

Communicated by Roland A. Brandl.

Hannu Ylönen

hannu.j.ylonen@jyu.fi

Rolf A. Ims

rolf.ims@uit.no

1 Department of Biological and Environmental Science, Konnevesi Research Station, University of Jyväskylä, P.O. Box 35, FIN 40014 Jyväskylä, Finland

2 Department of Arctic and Marine Biology, University of Troms $\varnothing$, The Arctic University of Norway, Tromso, Norway in population ecology and dean at Evenstad, he expanded his study systems to free-living small mammal populations around the Evenstad campus and well beyond in terms of other species and locations. Population regulation mechanisms were always close to his heart, in studies where Harry combined behavioural ecology and evolutionary processes in the study of population fluctuations. Harry had a great passion for research and teaching, support for international research networks and mentoring of young scientists. He initiated an international research school in applied ecology (IRSAE) that currently involves about $200 \mathrm{PhD}$ students and 50 researchers.

Harry visited the University of Jyväskylä several times, often in relation to the Konnevesi Research Station Winterschool of Ecology workshops. His last visit to Konnevesi was the workshop on "Population cycles and outbreaks: Still of interest or historical debate?" in February 2018. During this visit, Harry was well, despite hard medical treatments just ending before the workshop. This paper is based on the idea of us three organizers, Harry, Janne Sundell and the first author of this obituary. We were happy to accept Harry's offer to coordinate the planning and writing of the manuscript initially. Harry worked hard in the project all moments his advancing sickness made it possible. In May 2019, Harry passed away and never saw this contribution ready. All authors, who had been contributing to the discussion and writing of this review, decided to go on and to honour Harry's excellent research career by completing the project with Harry's first authorship, as planned. Population ecological research, and the Northern vole cycle mafia, have lost a dear friend. Besides being a dedicated scientist, Harry was in his silent way a bit enigmatic person, together in being a warm lover of social events, good food and academic discussions. We all miss you, Harry. 


\section{References}

Andreassen HP, Sundell J, Ecke F, Halle S, Haapakoski M, Henttonen H, Huitu O, Jacob J, Johnsen K, Koskela E, Luque-Larena JJ,

Lecomte N, Leirs H, Mariën J, Neby M, Rätti O, Sievert T, Singleton GR, van Cann J, Broecke BV, Ylönen H (2020) Population cycles and outbreaks of small rodents: ten essential questions we still need to solve. Oecologia. https://doi.org/10.1007/s00442-02004810-w 